\title{
Description of fourth instar larva and pupa of Atrichopogon delpontei Cavalieri and Chiossone (Diptera: Ceratopogonidae) from Brazilian Amazonia
}

\author{
PABLO I. MARINO ${ }^{1}$, GUSTAVO R. SPINELLI ${ }^{1}$, RUTH FERREIRA-KEPPLER ${ }^{2}$ and MARÍA M. RONDEROS ${ }^{1,3}$ \\ ${ }^{1}$ División Entomología, Museo de La Plata, CCT-CEPAVE-ILPLA, Paseo del Bosque s/n, 1900 La Plata, Argentina \\ ${ }^{2}$ Instituto Nacional de Pesquisas da Amazônia, Coordenação de Biodiversidade, Av. \\ André Araújo, 2936, Petrópolis, 69067-375 Manaus, AM, Brazil \\ ${ }^{3}$ Centro de Estudios Parasitológicos y de Vectores/CEPAVE, Facultad de Ciencias Naturales \\ y Museo/UNLP, Consejo Nacional de Investigaciones Científicas y Técnicas/CONICET, \\ Boulevard 120 s/n e/ Avda. 60 y calle 64, 1900 La Plata, Buenos Aires, Argentina
}

Manuscript received on April 7, 2015; accepted for publication on May 23, 2016

\begin{abstract}
The fourth instar larva and pupa of Atrichopogon delpontei Cavalieri and Chiossone are described for the first time. The immatures were collected from stream margins in the northern Brazilian states Rondônia and Piauí, and subsequently reared to adults. Larvae and pupae are illustrated and photomicrographed. Details on the rearing process and feeding behavior in laboratory, bionomics and notes on habitats are also provided.
\end{abstract}

Key words: Atrichopogon delpontei, immatures, Lophomyidium, Neotropical region, reared.

\section{INTRODUCTION}

The worldwide genus Atrichopogon Kieffer, one of the most speciose in the family Ceratopogonidae, includes species that are very similar in appearance and most of them cannot be confidently identified (Edwards 1926, Debenham 1973, Borkent and Picado 2004, Spinelli and Marino 2007). In contrast to this the immature stages are excellent for species recognition (Nielsen 1951, Ewen and Saunders 1958, Chan and Linley 1988, Szadziewski et al. 1995). Some live in moist, terrestrial habitats of decaying organic matter like dung or rotting wood, and others develop in aquatic and semiaquatic

Correspondence to: María M. Ronderos

E-mail: ronderos@fcnym.unlp.edu.ar habitats (hygropetric) on partially submerged stones, rotting wood, algae or mosses along the margins of streams, ponds or lakes (Szadziewski et al. 1997). Borkent and Spinelli (2007) catalogued 100 species for the Neotropics, and eight more were subsequently described for the Region. Of this number, the subgenus $A$. (Lophomyidium Cordero) includes only the following eight species: A. archboldi Wirth, A. delpontei Cavalieri and Chiossone, A. fusculus (Coquillett), A. ocumare (Ortiz), A. setosilateralis Borkent and Picado, A. taeniatus Macfie, A. tapantiensis Borkent and Picado, and $A$. uruguayensis Cordero. Larval and pupal stages are only known for A. fusculus, briefly described by Ewen and Saunders (1958). 
The purpose of this paper is to fully describe for the first time with modern standars, the fourth instar larva and pupa of $A$. delpontei from specimens recently collected in northern Brazil.

\section{MATERIALS AND METHODS}

Field work was conducted between 2011 and 2012 in the states of Rondônia and Piauí (Fig. 43).

Larvae and pupae were collected at river margins with a pair of tweezers. Larvae were preserved in ethanol $80 \%$ and pupae were kept alive isolated in $2 \mathrm{~mm}$ plastic vials, containing a piece of wet filter paper to maintain humidity. They were observed daily until adult emergence. After emergence adults were kept alive for 24 hours before being preserved to ensure their pigmentation was complete. They were subsequently stored in vials containing ethanol $80 \%$ with their respective exuviae. Larval and pupal exuviae and adults were slide mounted in Canada balsam following the technique described by Borkent and Spinelli (2007). Specimens were examined, measured and drawn using a binocular compound microscope. Illustrations were made with pen and ink using an attached camera lucida. Photographs were taken with a Micrometrics SE Premium digital camera, through a Nikon Eclipse E200 microscope. For scanning electron microscopy (SEM), larvae and pupae were prepared following the technique of Ronderos et al. (2000, 2008). Photomicrographs were taken with JSM6360LV.

For larval terminology see Marino et al. (2010) and Murphee and Mullen (1991), and Borkent (2014) for pupal terminology. The map was traced from SIGMINE and can be visualized in: http:// sigmine.dnpm.gov.br/webmap/. The plate was made in TIFF format in Adobe Photoshop version 14.0.

Studied specimens are deposited in the collections of the Instituto Nacional da Pesquisas da
Amazonia (INPA) and the División Entomología, Museo de La Plata, Argentina (MLPA).

\section{Atrichopogon (Lophomyidium) delpontei Cavalieri and Chiossone (Figures 1-42)}

Atrichopogon delpontei Cavalieri and Chiossone, 1972: 121 (male, female; Argentina); Spinelli and Wirth, 1993: 23 (in list; Argentina); Wirth, 1994: 24 (notes); Borkent and Wirth, 1997: 23 (in World catalogue); Borkent and Spinelli, 2000: 10 (in catalogue south of USA); Borkent and Spinelli, 2007: 45 (in Neotropical catalogue); Borkent, 2016: 20 (in online World catalogue).

Adult diagnosis. The only species of Atrichopogon (Lophomyidium) in the New World in which male have a six scutellar setae, the sternite 9 is deeply excavated and the distal margin of the aedeagus-parameral complex is pointed. Female have six scutellar setae, flagellomeres 9-13 elongate, palpus entirely brown, wing very hairy with more than 50 large macrotrichia in anal cell and small, unequal spermathecae with short necks.

Fourth instar larva (Figs. 1-20, 34-39). Total length 3.56-4.02 (3.74, $\mathrm{n}=4) \mathrm{mm}$. Color in life yellowish brown except head capsule dark brown. Head capsule (Figs. 1-4, 15-16, 34-35) 1.15 $\mathrm{X}$ longer than broad, brown. HL 0.46-0.47 (0.47, $\mathrm{n}=4) \mathrm{mm}$, HW 0.40-0.42 (0.41, n=4) mm, HR 1.09$1.18(1.13, n=4)$, SGW 0.25-0.27 (0.26, n=4), SGR 1.56-1.64 (1.59, n=4). Antenna long, located on stout tubercle (Figs. 2-4, 34). Head chaetotaxy as in Figs. 2-4, 34-35, all setae simple. Labrum (Fig. 5 ) as long as its greatest (basal) width; palatum (Figs. 5-6, 18) with three anterolateral sensilla styloconica on anterior edge, two posterior sensilla trichoidea on each side (Fig. 6); messors (Figs. $6,17,36)$ well developed, sinuous; scopae well developed with short, medium-sized teeth (Fig. 6), palatal bar present (Figs. 5, 8). Mandible (Figs. 1618) scooped, broad, with three teeth, one apical, rounded tooth, two subapical teeth, one short, other 

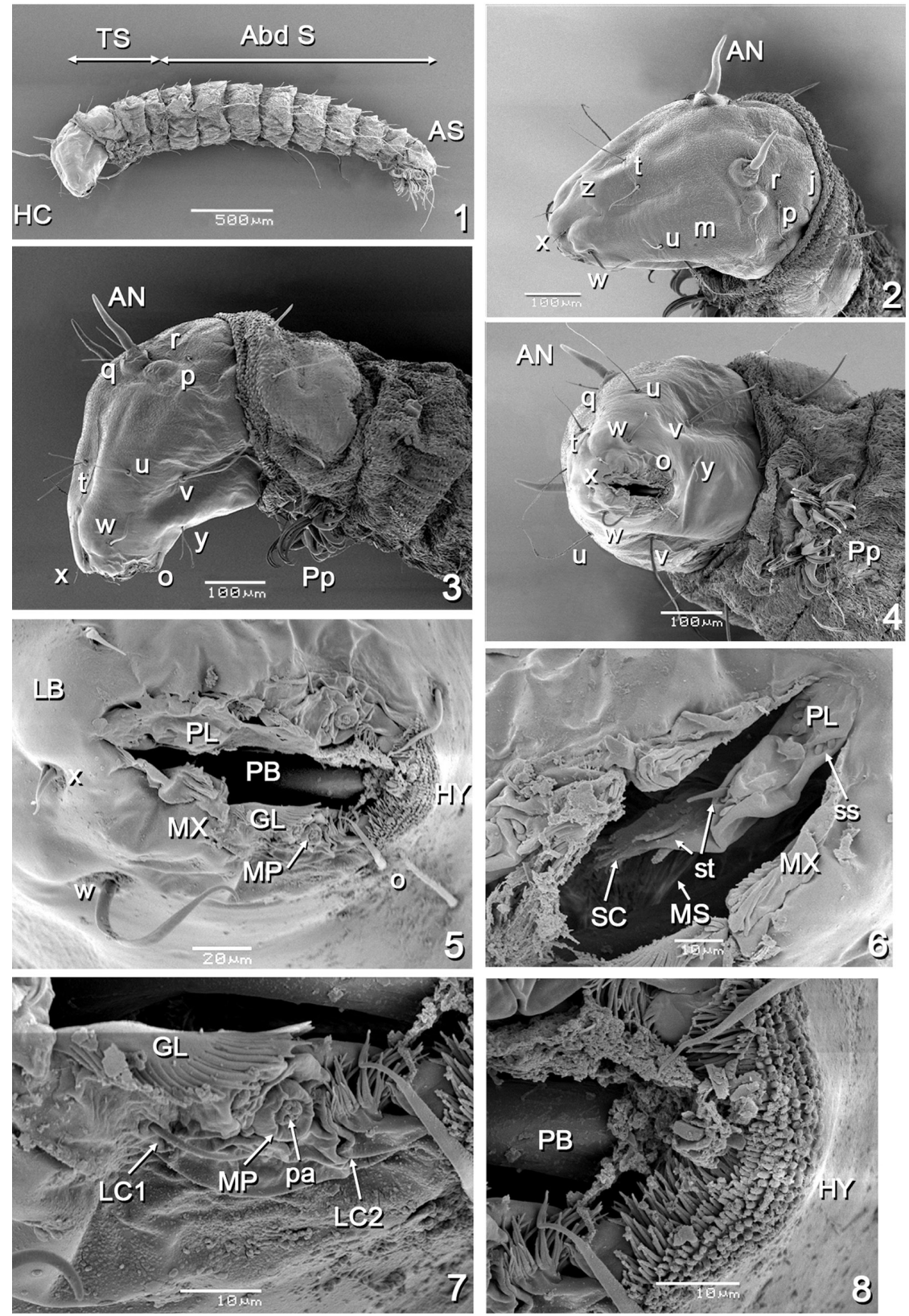

Figures 1-8 - Atrichopogon delpontei, larva. (1) entire larva, lateral view; (2) head capsule chaetotaxy, dorsolateral view; (3) head capsule chaetotaxy, lateral view; (4) head capsule, anteroventral view; (5) head capsule in detail, frontal view; (6) mouthparts in detail, frontal view; (7) details of maxilla; (8) details of hypostoma and palatal bar.

Abdominal segments (Abd S); anal segment (AS); antenna (AN); galeolacinia (GL); head capsule (HC); hypostoma (HY); lacinial sclerite 1 (LC1); lacinial sclerite 2 (LC2); labrum (LB); maxilla (MX); maxillary palpus (MP); messors (MS); mediodorsal seta (mst); papillae (pa); palatal bar (PB); palatum (PL); prothoracic proleg (Pp); scopae (SC); sensilla styloconica (ss); sensilla trichoidea (st); thoracic segments (TS). Head capsule chaetotaxy: j, collar pits; m, posterolateral pits; o, parahypostomal setae; $p$, posterior perifrontal setae; q, postfrontal seta; $r$, postnotal pits; $t$, prefrontal seta; $u$, mesolateral seta; v, posterolateral seta; w, anterolateral seta; $x$, paranntenal setae; y, ventral seta; $z$, frontal pits. 
elongate, MDL 0.11-0.13 (0.12, n=4) mm, MDW 0.026-0.030 (0.029, n=4) mm. Maxilla (Figs. 5-6) bilobed with fringe on external margins; maxillary palpus short, flattened, with four subapical papillae (Figs. 5, 7); lacinial sclerite 1 with long, stout seta (Fig. 7), lacinial sclerite 2 without seta (Fig. 7). Hypostoma (Figs. 5, 8) with fine crenulations in 5-6 rows along its entire width. Epipharynx (Figs. 9-11, 15-16, 19, 37-38) massive, strongly sclerotized, dorsal comb with numerous (28-30) stout teeth along posterior margin of median sclerite, ventral comb massive (Fig. 10), lateral arms short, stout (Figs. 19, 37). Hypopharynx (Fig. 38) sclerotized, lateral arms long, thin, without fringe; LAW 0.22$0.26(0.24, \mathrm{n}=4) \mathrm{mm}, \mathrm{DCW}$ 0.070-0.074 (0.071, $\mathrm{n}=4)$. Thoracic, abdominal segments very broad, each with double row of mediodorsal, spine-like setae (Figs. 3, 12, 14, 20). Thoracic, abdominal pigmentation entirely pale brown, prothorax with two dark lateral patches. Dorsal surface of prothorax with plate bearing two strong setae (Figs. 3, 12); prothoracic proleg bifid (Figs. 3-4), each half with six dark brown, posteriorly directed hooks, seven anterior hyaline hooklets, one medially directed, other six posteriorly directed. Chaetotaxy of second abdominal segment as in Fig. 39; dorsally, one stout, medium-sized seta "a", with dark, conical base; laterally, four setae, seta "b" stout, medium-sized, longer than "a", with dark, conical base; "c" long, hyaline, stout seta, with pale, conical base, "d" and "e" medium-sized, thin setae, "d" longer than "e", "e" is situated on base of "c"; ventrally, "f" and "g" each a short seta, "h" medium-sized, thin seta. Anal segment (Figs. 13$14,20)$ with dorsal, rectangular, pigmented plate bearing one long, strong seta, and with five setae, two of these long, stout, pale brown, other three thin, short, dark brown. CSL 0.29-0.30 $(0.30, n=4)$ mm, CSW 0.34-0.36 (0.36, n=4) mm, CSR 0.80$0.86(0.83, \mathrm{n}=4)$, OL 0.25-0.35 (0.29, $\mathrm{n}=4) \mathrm{mm}$, OD 0.21-0.24 (0.23, $\mathrm{n}=4) \mathrm{mm}$. Anal proleg (Fig. 20) bilobed, each lobe with row of 12-13 ventrolateral, posteriorly directed, dark brown hooks, one row of 10 hyaline hooklets. Anal papilla hyaline, with two/ three pairs of papillae on each side.

Male pupa (Figs. 28-29, 40-42). Total length 2.90-3.16 $(3.04, \mathrm{n}=4) \mathrm{mm}$. General coloration of exuviae brown. Cephalothorax surface with tiny rounded tubercles, length 1.52-1.66 $(1.59, \mathrm{n}=4)$ $\mathrm{mm}$, width 0.92-1.16 (1.05, $\mathrm{n}=4) \mathrm{mm}$. Dorsal apotome (Fig. 29) triangular, 0.5 X longer than broad, surface covered with small spicules mainly on posterior margin, anterolateral margin smooth, anterior margin nearly straight, posterior margin rounded; dorsal apotome sensillum: DA-1-H long, stout seta on prominent tubercle (Fig. 29); DAL 0.11-0.14 (0.13, n=4) mm; DAW 0.26-0.29 $(0.28, \mathrm{n}=4) \mathrm{mm}, \mathrm{DAW} / \mathrm{DAL}$ 2.00-2.36 (2.15, $\mathrm{n}=4)$. Cephalothoracic sensilla as follows: two dorsolateral cephalic sclerite sensilla, DL-1-H elongate seta, DL-2-H campaniform sensillum; anterolateral sensilla: AL-1-T long, thin seta, AL-2-T not visible in examined specimens; anteromedial sensillum: AM-1-T campaniform sensillum; dorsal setae (Fig. 40) as follows: D-1-T long, thin seta, D-2-T, T-1-T elongate tubercles without setae, and T-2-T short tubercle without seta, D-3-T campaniform sensillum; supraalar (SA-2-T) campaniform sensillum. Respiratory organ (Fig. 28) brownish, 1.35 X longer than broad, surface with sparsely covered with large scale-like tubercles, with a U-shaped double row of 18-20 apical, two lateral conspicuous pores; RO length 0.14-0.15 (0.15, $\mathrm{n}=4) \mathrm{mm}$, RO width 0.10-0.12 $(0.11, \mathrm{n}=4) \mathrm{mm}$; pedicel $(\mathrm{P})$ smooth, short, pedicel length 0.006-0.010 (0.008, $\mathrm{n}=4) \mathrm{mm}, \mathrm{P} / \mathrm{RO} 0.04$ $0.07(0.05, \mathrm{n}=4)$. Two clypeal/labral sensilla, one seta (CL-2-H), one campaniform sensillum (CL1-H); one ocular (O-2-H) campaniform sensillum. Abdominal segments 1-5 with elongate lateral tubercles, 6-8 devoid of tubercles. First abdominal segment (Fig. 41) with sensilla as follows: D-2-I long, stout seta on tubercle, D-4-I, D-7-I campaniform sensilla; 2 lateral sensilla, L-1-I 

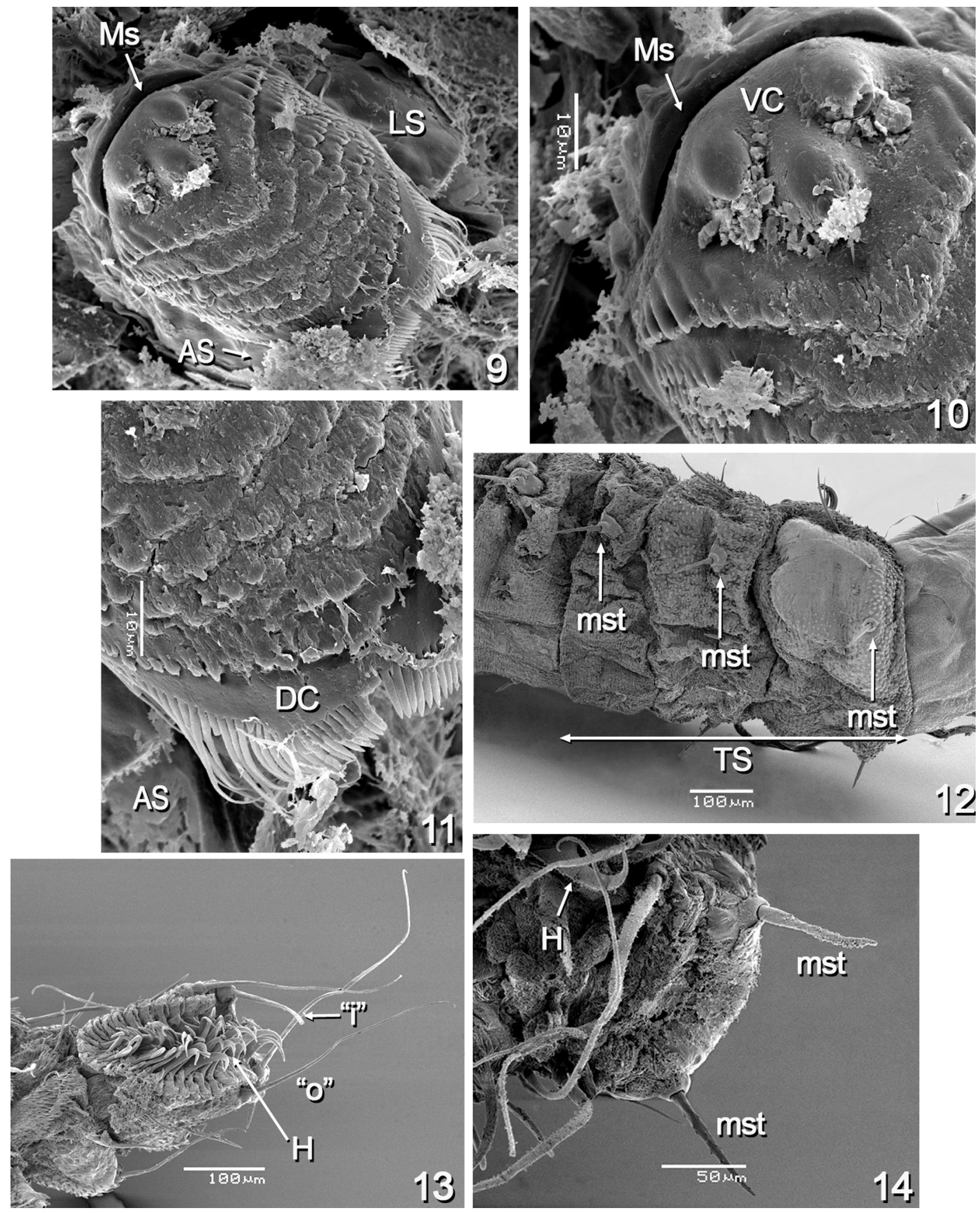

Figures 9-14 - Atrichopogon delpontei, larva. (9) epipharynx, dorsal view; (10) detail of epipharynx, anterior view; (11) detail of epipharynx, posterior view, dorsal comb; (12) thoracic segments; (13) anal segment, ventral view; (14) anal segment, dorsal view.

Auxiliary sclerite (AS); dorsal comb (DC); hooks (H); lateral sclerite (LS); median sclerite (Ms); mediodorsal seta (mst); thoracic segments (TS); ventral comb (VC); outer seta "o"; inner seta "i". 



Figures 15-20 - Atrichopogon delpontei, larva. (15) head capsule, ventral view; (16) detail of head capsule, anterior view; (17) frontal view, messors and mandible; (18) detail of mandible and palatum; (19) epipharynx; (20) anal segment. Scales $=0.05 \mathrm{~mm}$.

Dorsal comb (DC); dorsal plate (dPl); epipharynx (EPY); hooks (H), hooklets (Hlts); hypopharynx (HYP); lateral arms (LA); mandible (MD); median sclerite (Ms); messors (MS); palatum (PL); ventral comb (VC); outer seta "o"; inner seta "i"; mediodorsal seta (mst). 

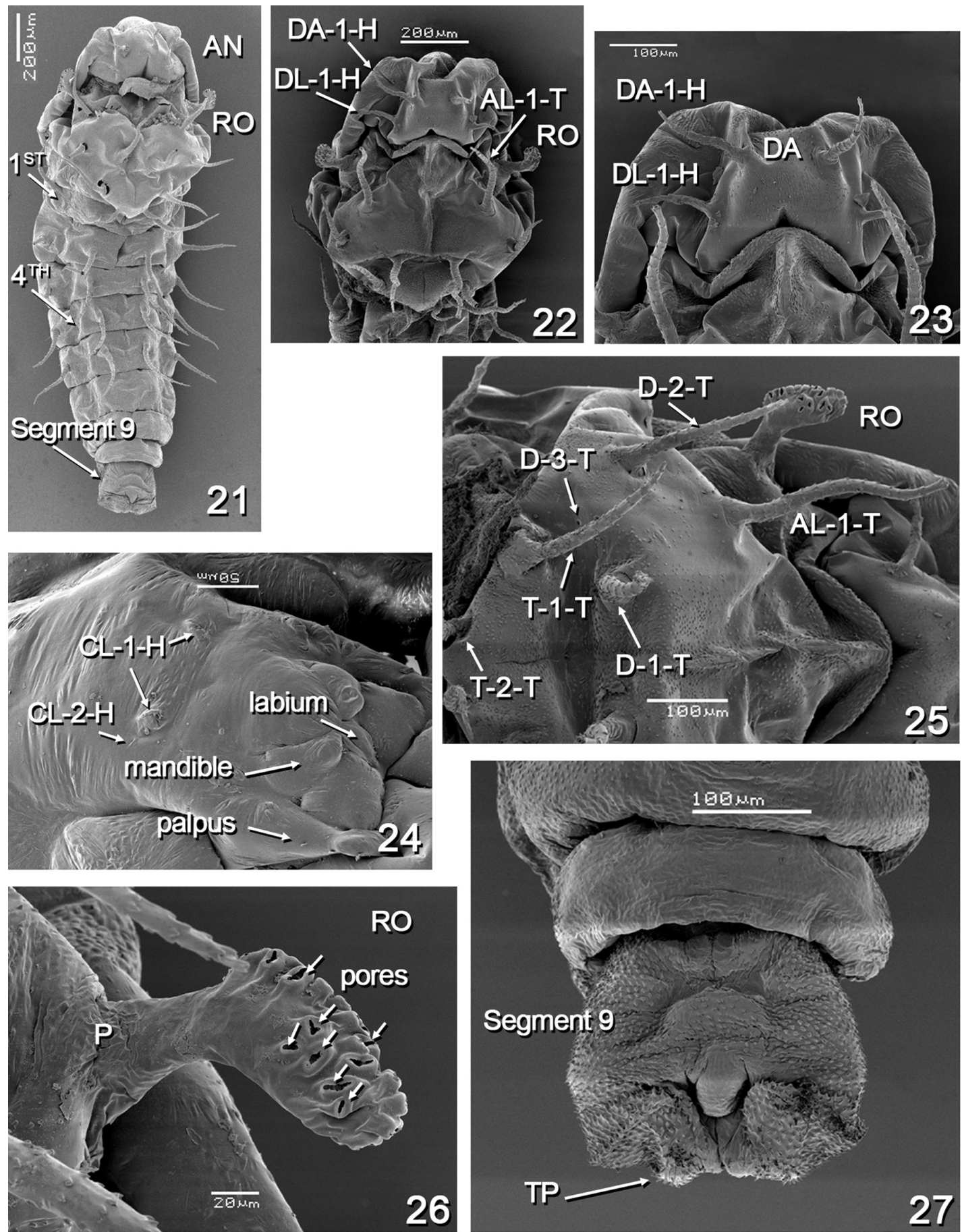

Segment 9

Figures 21-27 - Atrichopogon delpontei, female pupa. (21) entire pupa, dorsal view; (22) cephalothorax, dorsal view (dorsal apotomals sensillum, dorsolateral sensillum and anterolateral sensillum), (23) details of dorsal apotomal sensillum and dorsolateral sensillum; (24) details of mouthparts and clypeal/labral sensilla, ventral view; (25) dorsal setae, dorsal view; (26) respiratory organ; (27) Segment 9, dorsal view. Scales $=0.05 \mathrm{~mm}$.

Antenna (AN); anterolateral sensillum (AL-1-T); clypeal/labral sensillum (CL-1-H, CL-2-H), dorsal apotome (DA); dorsal apotomal sensillum (DA-1-H); dorsolateral sensillum (DL-1-H); dorsals (D-1-T, D-2-T, D-3-T, T-1-T, T-2-T); pedicel (P); respiratory organ (RO); terminal process (TP). 
medium-sized, stout articulate seta on elongate, spiculate tubercle, L-2-I short, thin seta without tubercle. Second abdominal segment similar to first except for the absence of L-2-I. Segment 4 with sensillar pattern (Fig. 42) as follows: D-2-IV medium-sized, stout articulate seta on elongate, spiculate tubercle, D-4-IV, D-7-IV campaniform sensilla; L-2-IV medium-sized, stout articulate seta on elongate, spiculate tubercle, L-4-IV short, thin seta; V-6-IV, V-7-IV short, thin setae, each on small tubercle. Segment 91.90 X longer than width, ventral surface with anterior band of spicules; length 0.24-0.26 $(0.25, \mathrm{n}=4) \mathrm{mm}$, width $0.30-0.32$ $(0.31, \mathrm{n}=4) \mathrm{mm}$. Terminal processes triangular, slightly divergent; length $0.040 \mathrm{~mm}$; D-5-IX and D-6-IX sensilla not visible in available specimens. Larval exuviae retained on the last segments of pupal abdomen (Fig. 28).

Female pupa (Figs. 21-27, 30-33). Similar to male with usual sexual differences. Total length 3.00-3.16 (3.08, $\mathrm{n}=2) \mathrm{mm}$. Exuviae pale brown. Cephalothorax (Fig. 21) length 1.64-1.68 (1.66, $\mathrm{n}=2) \mathrm{mm}$, width 1.06-1.16 (1.12, n=3) mm. Dorsal apotome (Figs. 23, 30-31) with DAL 0.14-0.17 $(0.16, \mathrm{n}=3) \mathrm{mm}$; DAW 0.32-0.33 (0.325, $\mathrm{n}=3) \mathrm{mm}$; DAW/DAL 1.90-2.27 (2.07, n=3). Clypeal/labral sensilla as in Figs. 24, 32. Dorsolateral cephalic sclerite sensilla, anterolateral seta and dorsal setae as in Figs. 22-23, 25. Respiratory organ (Figs. 21-22, 25-26), RO length 0.14-0.15 $(0.145, \mathrm{n}=3)$ $\mathrm{mm}, \mathrm{RO}$ width $0.10-0.13(0.115, \mathrm{n}=3) \mathrm{mm}$; pedicel length $0.010-0.012(0.011, \mathrm{n}=3) \mathrm{mm}, \mathrm{P} / \mathrm{RO} 0.066$ $0.086(0.074, \mathrm{n}=3) \mathrm{mm}$. Segment 9 (Fig. 27) length 0.20-0.23 (0.22, $\mathrm{n}=2) \mathrm{mm}$, width 0.30-0.32 (0.31, $\mathrm{n}=2) \mathrm{mm}$. Terminal processes triangular, slightly divergent, its bases well separated by a medial, truncate, nearly transverse area; each strong, spiculate over all entire surface; base broad with rounded tip, bent on photomicrographed specimen.

Material examined. Brazil, Piauí, Aroases municipality, Rio Sambito (06 13 '08.2''S/ 4151'05.6”W), 8-VI-2011, N. Hamada, 2 males,
1 female, 2 pupae with larval exuviae, 2 larvae plus 1 larval exuviae in one slide; Rondônia, Colorado do Oeste municipality, eixo zero, Rio Hermes (13¹2'07.6”S 60²3'25.1”W), 6-IX-2012, N. Hamada, 5 males, 1 female with pupal and larval exuviae, 1 female with pupal exuvia, 2 larvae on one slide, reared in laboratory; same data except 11IX-2012, 1 female with pupal and larval exuviae; same data except 30-IV-2012, 2 males with pupal exuviae.

Material examined by SEM. 2 larvae, 2 pupae, Brazil, Piauí, Aroases municipality, Rio Sambito (06¹3'08.2”S/ 4151'05.6”W), 8-VI-2011, N. Hamada.

Distribution. Northern Brazil (Piauí and Rondônia states), northeastern Argentina (Formosa, Chaco, and Santa Fe provinces).

Taxonomic discussion. Atrichopogon delpontei belongs to the subgenus Lophomyidium, as it was pointed out by Wirth (1994). The study of the holotype of $A$. delpontei deposited in the collection of the MLPA, reveals that it possesses six stout bristles on the scutellum instead of the four bristles mentioned by Cavalieri and Chiossone (1972) in the original description, as well as in the notes provided by Wirth (1994) in the revision of the Nearctic species of the subgenus. Therefore, considering that $A$. delpontei possesses six scutellar bristles, it should key out to couplet 4 in Wirth (1994) where it may be distinguished from Atrichopogon archboldi by the excavation of the male sternite 9 (deeply excavated in A. delpontei, slightly excavated in $A$. archboldi) and by the distal margin of the aedeagus-parameral complex (pointed in A. delpontei, rounded in A. archboldi). The female is almost indistinguishable from $A$. archboldi, except for the very hairy anal cell with more than 50 macrotrichia (28-35 in A. archboldi) and the spermathecae with short necks (without necks in $A$. archboldi).

The only description of larva and pupa of a species belonging to the subgenus Lophomyidium 

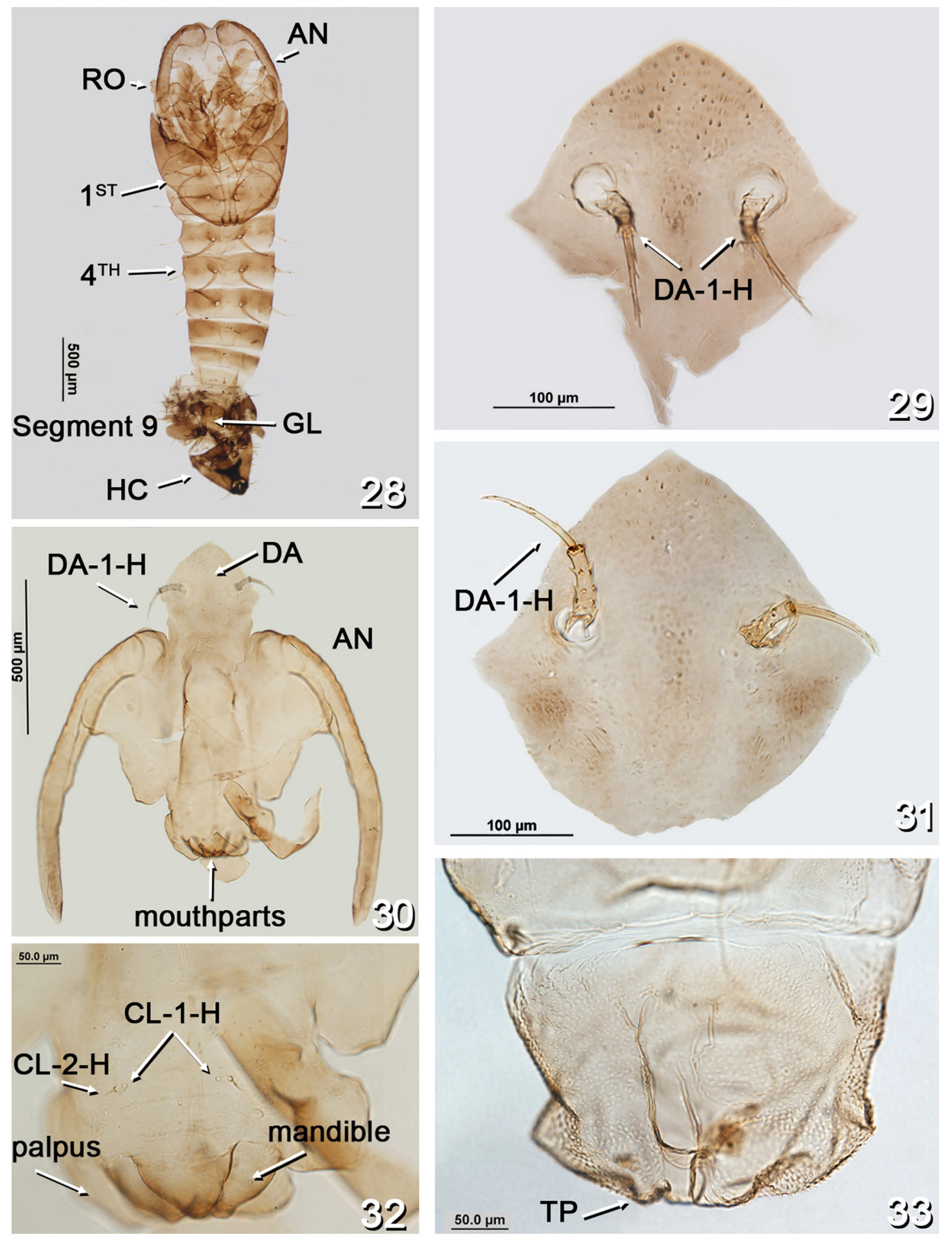

Figures 28-33 - Atrichopogon delpontei, pupa. Figures 28-29, male pupa. Figures 30-33, female pupa. (28) male pupa with retained larval exuviae, ventral view; $(\mathbf{2 9}, \mathbf{3 1})$ dorsal apotome, dorsal view; $(\mathbf{3 0})$ dorsal apotome with dorsal apotomal sensillum and mouthparts; (32) details of mouthparts and clypeal/labral sensilla; (33) segment 9 , ventral view. Scales $=0.05 \mathrm{~mm}$.

Antenna (AN); clypeal/labral sensilla (CL-1-H, CL-2-H); dorsal apotome (DA); dorsal apotomal sensillum (DA$1-\mathrm{H})$; genital lobes $(\mathrm{GL})$; head capsule $(\mathrm{HC})$; respiratory organ $(\mathrm{RO})$; terminal process $(\mathrm{TP})$. 

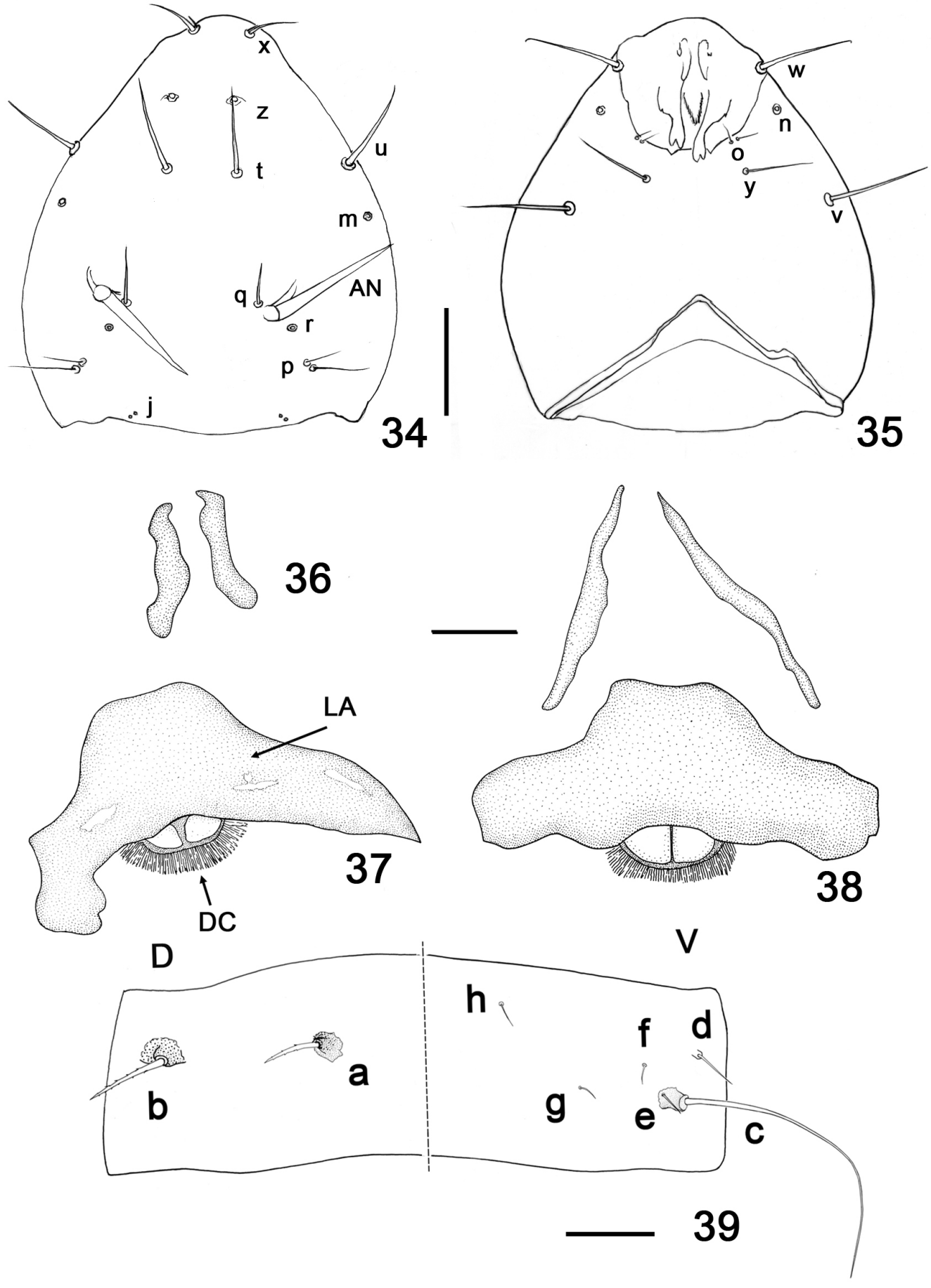

Figures 34-39 - Atrichopogon delpontei, larva. (34) Head capsule chaetotaxy, dorsal view; (35) Head capsule chaetotaxy, ventral view; (36) messors; (37) epipharynx, dorsal view; (38) hypopharynx and epipharynx, ventral view; (39) chaetotaxy of second abdominal segment. Scales $=0.05 \mathrm{~mm}$.

Antenna (AN); dorsal comb (DC); lateral arms (LA). Head capsule chaetotaxy: j, collar pits; m, posterolateral pits; $\mathrm{n}$, anterolateral pits; $\mathrm{o}$, parahypostomal setae; $\mathrm{p}$, posterior perifrontal setae; $\mathrm{q}$, postfrontal seta; r, postnotal pits; $t$, prefrontal seta; $u$, mesolateral seta; v, posterolateral seta; w, anterolateral seta; $x$, paranntenal setae; $y$, ventral seta; $z$, frontal pits. 

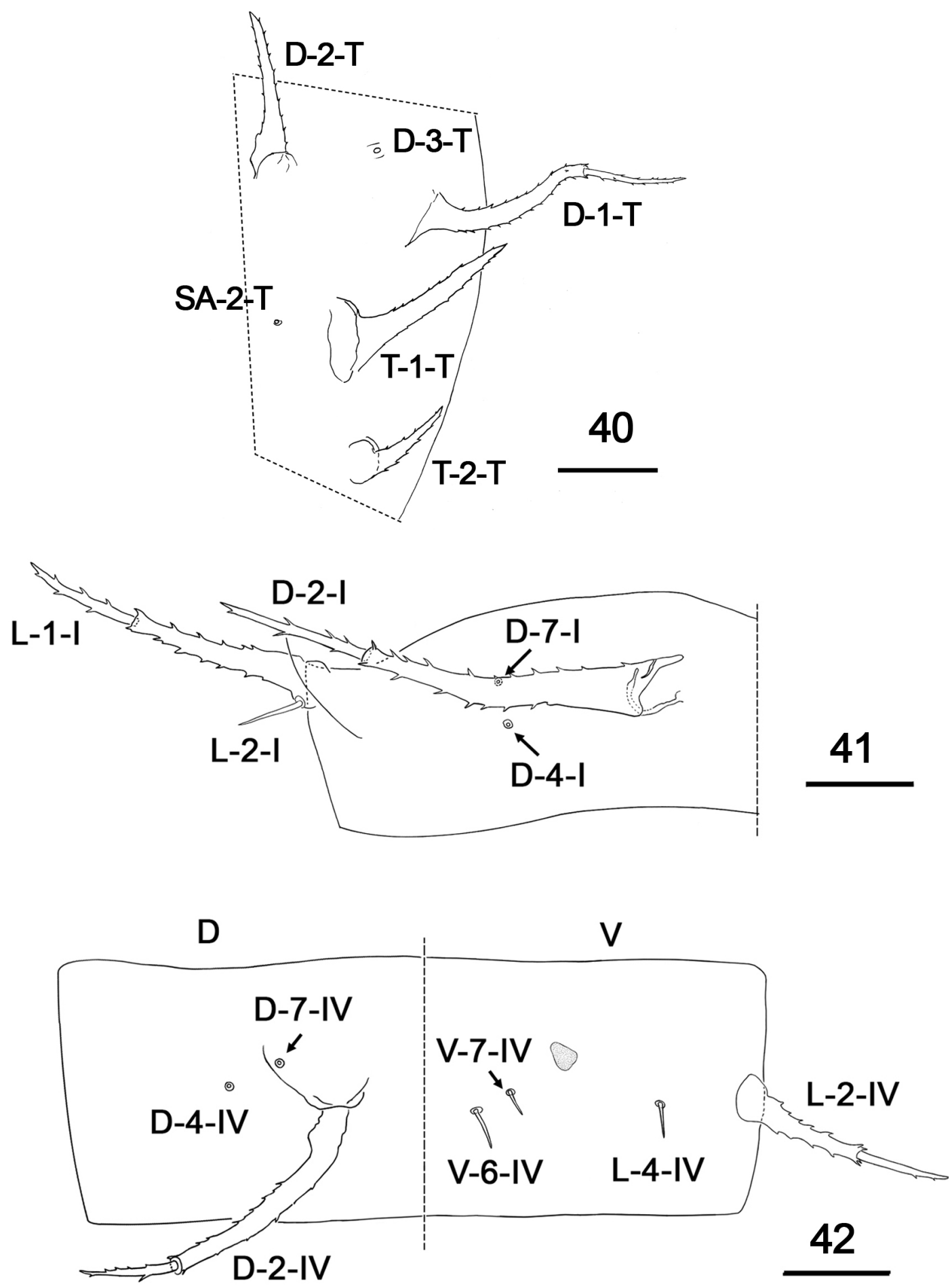

Figures 40-42 - Atrichopogon delpontei, male pupa. (40) dorsal setae; (41) first abdominal segment, dorsal view; (42) fourth abdominal segment, dorsal and ventral view. Scales $=0.05 \mathrm{~mm}$.

Dorsal setae and supraalar (D-1-T, D-2-T, D-3-T, T-1-T, T-2-T, SA-2-T); dorsal sensilla of first abdominal segment (D-2-I, D-4-I, D-7-I); dorsal sensilla of fourth abdominal segment (D-2-IV, D-4-IV, D-7-IV); lateral sensilla of first abdominal segment (L-1-I, L-2-I); lateral sensilla of fourth abdominal segment (L-2-IV, L-4-IV); ventral sensilla of fourth abdominal segment (V-6-IV, V-7-IV). 


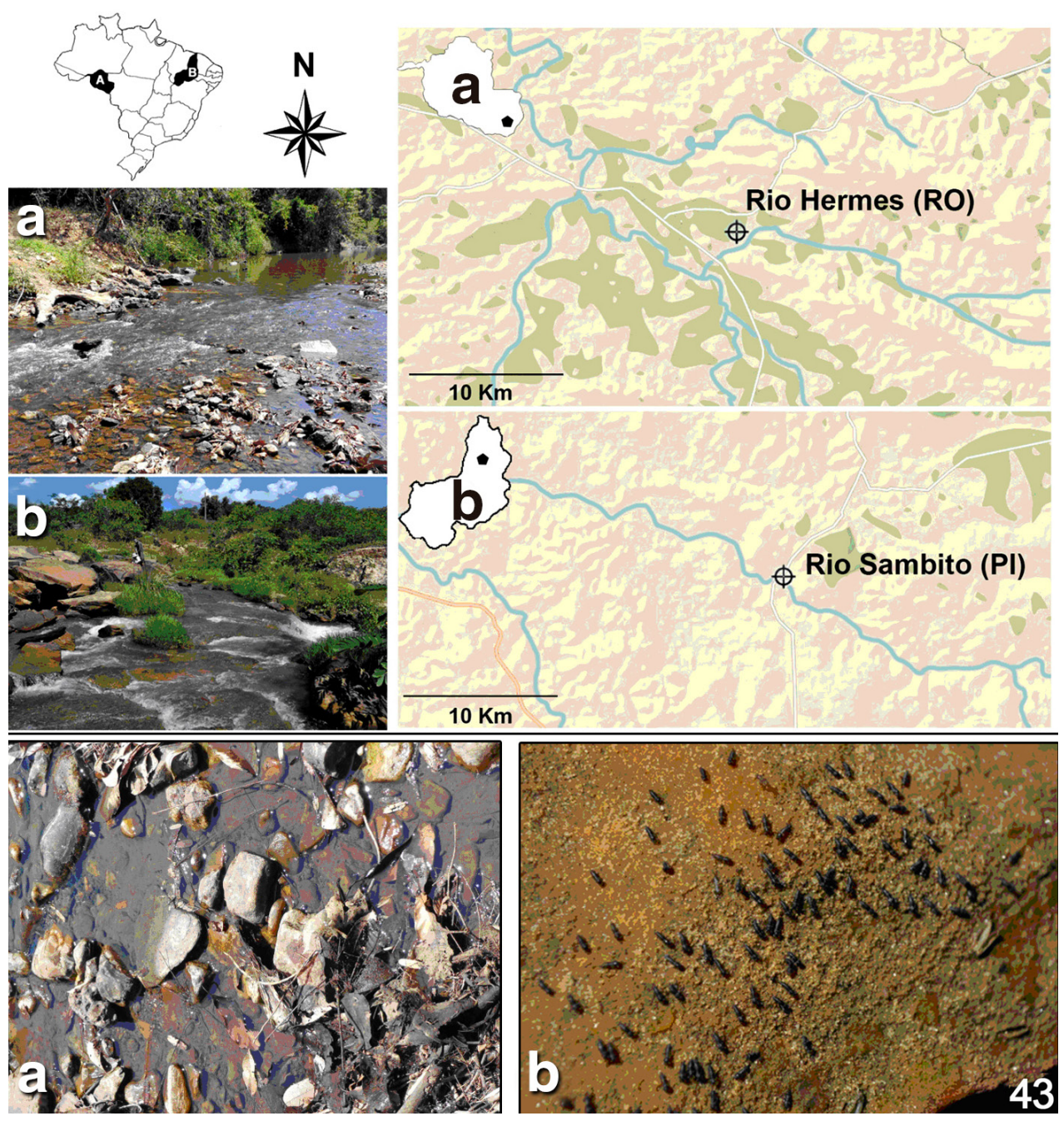

Figure 43 - Collecting sites. Location of the two rivers. (a) Rio Hermes (Rondônia state), (b) Rio Sambito (Piauí state).

is the one provided by Ewen and Saunders (1958) for Atrichopogon fusculus, whose adults bear four scutellar bristles. It is very incomplete, and therefore it is very difficult to compare the immatures of $A$. fusculus with those of $A$. delpontei, herein described. However, the larvae of both species share a similar chaetotaxy of the head capsule, and the anal segment of the larvae of $A$. fusculus bears two pairs of long setae, but the posterolateral pair is stronger. The larva of $A$. delpontei possess scopae. and palatal bar, two structures that still were undescribed in any larvae of this genus, and the prothorax has a dorsal plate bearing two strong setae.

With regard to the pupa, Borkent (2014) mentioned for Atrichopogon that the fourth segment lacks lateral setae or bears a single one (L-1-IV), but $A$. delpontei clearly exhibits two lateral setae (L-2-IV and L-4-IV). Furthermore, the pupa of $A$. delpontei shows the following distinctive features: the dorsal apotome lacks a medial tubercle on its posterior margin, and the terminal process is short and directed laterally.

Bionomics. The larva of $A$. delpontei exhibits a toothed mandible without fossa mandibularis and 
hypognathous mouthparts, typical of herbivorous larvae whose feed diatoms, bacteria, fungi and other algae (Thomsen 1937, Hribar 1993). Moreover, it presents a conspicuous, sclerotized epipharynx that is used to scrape on the bottom of the streams where it lives.

Notes on habitats. The width of the sampled rivers varied from 8-10 m, the stream bed was composed of sand, small rocks and boulders. Rio Hermes water temperature was $27.5^{\circ} \mathrm{C}$, pH 7.9 and conductivity $173.2 \mu \mathrm{Scm}^{-1}$, while and Rio Sambito water temperature was $26.5^{\circ} \mathrm{C}, \mathrm{pH} 7.3$ and conductivity $100.7 \mu \mathrm{Scm}^{-1}$. Specimens were collected in the shallowest portions of the rivers $(5-30 \mathrm{~cm})$.

Larvae and pupae were found in deciduous leaves accumulated on the rocks located on the margins of the Rio Hermes; larvae occupied the submerged side of the leaves and pupae the upper side above the water, very exposed to the sunlight. At Rio Sambito larvae were collected from submerged rocks and pupae above the water, on rocks exposed to strong sunlight (Fig. 43).

Pupae resist the high temperatures of the exposed rocks, and retain the larval exuviae with their terminal processes (Hamada, pers. com.). They adhere to the rocks by the claws of the larval exuviae, keeping a vertical position.

\section{ACKNOWLEDGMENTS}

We are very grateful for the support of Instituto Nacional de Pesquisas da Amazônia (INPA)/ Ministério da Ciência, Tecnologia e Inovações (MCTI)andConselhoNacionalde Desenvolvimento Científico e Tecnológico (CNPq)/ MCTI projects coordinated by Dra. Neusa Hamada, who kindly provide the material herein described. Our gratitude also to J.M.C. Nascimento and R.B. Querino for their collaboration in the field. We are grateful to PIP 0305-CONICET for economic support during this investigation, and to Nélida Caligaris and Luis Gianbelluca for technical assistance in the laboratory. We would like to acknowledge Dr. Art Borkent for the detailed critical review of the manuscript acting as a journal reviewer.

\section{REFERENCES}

BORKENT A. 2014. The pupae of the biting midges of the World (Diptera: Ceratopogonidae), with a generic key and analysis of the phylogenetic relationships between genera. Zootaxa 3879: 1-327.

BORKENT A. 2016. World species of biting midges (Diptera: Ceratopogonidae). http://wwx.inhs.illinois.edu/ files/1114/2384/5200/CeratopogonidaeCatalog.pdf, 245 p. Last update May 16, 2016.

BORKENT A AND PICADO A. 2004. Distinctive new species of Atrichopogon Kieffer (Diptera: Ceratopogonidae) from Costa Rica. Zootaxa 637: 1-68.

BORKENT A AND SPINELLI GR. 2000. Catalog of the New World biting midges south of the United States of America (Diptera: Ceratopogonidae). Contrib Entomol Int 4(1): 1-107.

BORKENT A AND SPINELLI GR. 2007. Neotropical Ceratopogonidae (Diptera: Insecta). In: Adis J, Arias JR, Rueda-Delgado G and Wantzen KM (Eds), Aquatic Biodiversity in Latin America (ABLA), Vol. 4. Pensoft, Sofia-Moscow, p. 1-198.

BORKENT A AND WIRTH WW. 1997. World species of biting midges (Diptera: Ceratopogonidae). Bull Am Mus Nat Hist 233: 1-257.

CAVALIERI F AND CHIOSSONE IF.1972. Notas sobre el género Atrichopogon Kieffer, 1906, de la Argentina (Diptera, Ceratopogonidae). I. Consideraciones generales y descripción de Atrichopogon delpontei sp. nov. Rev Soc Entomol Argent 34: 119-129.

CHAN KL AND LINLEY JR. 1988. Description of Atrichopogon wirthi new species (Diptera: Ceratopogonidae) from leaves of the water lettuce (Pistia stratiotes) in Florida. Fla Ent 71: 186-201.

DEBENHAM ML. 1973. Four New Guinea and northern Queensland species of Atrichopogon Kieffer (Diptera: Ceratopogonidae) with atypical development of the thoracic setae. J Aust Entomol Soc 12: 68-77.

EDWARDS FW. 1926. On the British biting midges (Diptera, Ceratopogonidae). Trans Entomol Soc London 74: 389426.

EWEN AB AND SAUNDERS LG. 1958. Contributions towards a revision of the genus Atrichopogon based on characters of all stages (Diptera. Heleidae). Can J Zool 36: 701-724.

HRIBAR LJ. 1993. Mouthpart morphology and feeding behavior of biting midges larvae (Diptera: 
Ceratopogonidae). In: Schaefer CW and Leschen RAB (Eds), Functional Morphology of Insect Feeding, Thomas Say Publications in Entomology: Proc Entomol Soc Amer Lanham, MD, p. 43-58.

MARINO PI, RONDEROS MM AND SPINELLI GR. 2010. Redescription of the immatures stages of Forcipomyia (Phytohelea) bromelicola (Lutz, 1914) (Diptera: Ceratopogonidae). Aquatic Insects 32(3): 205-213.

MURPHEE CS AND MULLEN GR. 1991. Comparative larval morphology of the genus Culicoides Latreille (Diptera, Ceratopogonidae) in North America with a key to species. Bull Soc Vector Ecol 16(2): 269-399.

NIELSEN A. 1951. Contributions to the metamorphosis and biology of the genus Atrichopogon Kieffer (Diptera, Ceratopogonidae) with remarks on the evolution and taxonomy of the genus. Biol Skr 6: 1-95.

RONDEROS MM, DIAZ F AND SARMIENTO P. 2008. A new method using acid to clean and a technique for preparation of eggs of biting midges (Diptera: Ceratopogonidae) for Scanning Electron Microscope. Trans Am Entomol Soc 134: 471-476.

RONDEROS MM, SPINELLI GR AND SARMIENTO P. 2000. Preparation and mounting of biting midges of the genus Culicoides Latreille (Diptera: Ceratopogonidae) to be observed with Scanning Electron Microscope. Trans Am Entomol Soc 126: 125-132.
SPINELLI GR AND MARINO PI. 2007. A new Neotropical species of Atrichopogon Kieffer and a redescription of $A$. casali Cavalieri \& Chiossone (Diptera: Ceratopogonidae). Stud Neotrop Fauna E 42: 203-209.

SPINELLI GR AND WIRTH WW. 1993. Los Ceratopogonidae de la Argentina (Insecta: Diptera). En: de Castellanos ZA (Ed), Fauna de agua dulce de la República Argentina. Vol. 38. Diptera Fascículo 3. Ceratopogonidae, p. 1-124.

SZADZIEWSKI R, GILKA W AND ANTON H. 1995. Immature stages of two European species of subgenus Meloehelea (Diptera, Ceratopogonidae), with key to the European subgenera Atrichopogon. Ent Scand 26: 181190.

SZADZIEWSKI R, KRZYWINSKI J AND GILKA W. 1997. Diptera Ceratopogonidae, biting midges. In: Nilsson AN (Ed), Aquatic Insects of North Europe - A Taxonomic Handbook, Vol. 2. Apollo Books, Stenstrup, Denmark, p. 243-263.

THOMSEN LC. 1937. Aquatic Diptera. Part V, Ceratopogonidae. Cornell Univ Agr Exp Sta Mem 210: 57-80.

WIRTH WW. 1994. The subgenus Atrichopogon (Lophomyidium) with a revision of the Nearctic species (Diptera: Ceratopogonidae). Insecta Mundi 8: 17-36. 